\title{
Het og vakker?
}

I denne kuldetiden er det fristende med en varm badstue. Over 14 sider i 1930 fortalte bylege i Bergen Robert Kloster (1873-1947) fra en reise i Finland der han på stipend hadde studert badstuer. Store deler av artikkelen omhandler ulike måter å bygge og innrede saunaer på og økonomi rundt vedfyring etc. Men også deres helsemessige innvirkning blir omtalt. Blant annet mente man at de var gunstige i forhold til tuberkulose og luftveisinfeksjoner - og utseendet (Tidsskr Nor Lægeforen 1930; 50: 364-79).

\section{Hygiene, social medisin, lægeforhold $\mathrm{m}$. v. \\ Finske badstuer.}

Stipendieberetning av Robert Kloster.

(...)

Det er påfallende hvor rene og propre alle samfundsklasser virker. På torv, i butikk, i sporvogn og jernbane og på fergen og rutebilen kan det nok merkes en og annen duft, som er karakteristisk for arbeidets art, men sur, impregnert, skidden lukt merkes ikke. Huden er fin og ren og gir selv mennesker, som ved første øiekast ikke synes særlig vakre, et friskt utseende og charme. Og læger og hudspesialister var enige om, at hudsykdommer er sjeldne i Finnland.

(...)

Badstuen, rene klær og rene omgivelser, frisk luft og hjemmebakt brød av sammalt mel karakteriserer gjennemgående den finske bonde. Det har ganske sikkert hevet folkets ydeevne og dets motstandsevne mot infeksjoner, samtidig som infeksjonsstoffet får vanskelige leveforhold og vaskes bort.

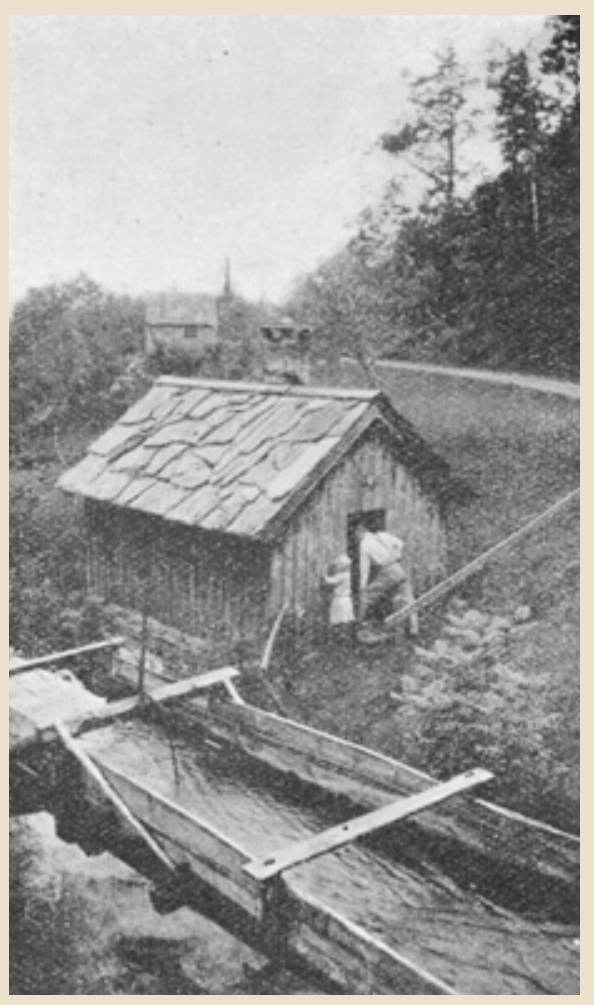

